\title{
Globální ohrožení lidstva chorobami a racionální vnímání rizika
}

\author{
Jaroslav Šimon \\ Centrum preventivní kardiologie, II. interní klinika, \\ Lékařská fakulta Univerzity Karlovy, Plzeň, Česká republika
}

Ptačí chřipka (virus H5N1) hubí ptactvo - nejdřive v Asii a Africe, nyní i v Evropě a Česku.

Existuje mnoho odborných označení virů a virových infekcí, ale málokterá se díky mediím dostala do obecného povědomí populace všech zemí, mužů i žen, dětí i starců, vzdělaných i nevzdělaných, jako virus HIV, virus SARS, dokonce i priony působící bovinní typ encefalopatie podobné lidské Creutzfeldtovy-Jacobovy (CJD) nemoci - populárně nazývané „nemoc šilených krav“. Lidé se báli jíst hovězí maso. Nynější paradigma k vyvolání paniky je H5N1. Všechna tato agens nejdříve hubila zviŕata, než se přenesla na člověka. U mnoha těchto obecně obávaných infekcí zůstal přenos na člověka pouze spekulativní. S dosti velkou pravděpodobností virus HIV byl přenesen na člověka od šimpanzů v Africe, snad pojídáním šimpanzího masa a syrového mozku zvírat. Podobně na Nové Guineji je endemická choroba kuru, přenášená rituálním pojídáním syrových mozků členů rodiny. Podobala se CJD. Španělská chřipka, která hubila populaci po 1. světové válce, pravděpodobně zmutovala $z$ viru prasat.

Je oprávněná panika $z$ přenosu a pandemie infekce virem H5N1? Důležitý je způsob přenosu a navyklý životní styl jednotlivých populací a celého lidstva. HIV se dále šiř́i a bude šiřit i přes známé možnosti prevence, protože sexuální aktivity všeho druhů i rizikový sex si lidstvo odedávna oblíbilo bez úvah o možném riziku.

H5N1 dnes hubí ptactvo a drůbež, tedy zdroje potravy bez kterých se neobejdeme. Infekcí přenášených od ptáků je řada. Po léta se u nás vyskytuje psitakóza (Chlamydia psittaci). Po špatné kuchyňské úpravě drůbeže můžeme dostat listeriózu nebo salmonelózu. Na tuto infekci občas někdo zemře, zejména staři a chronicky nemocní lidé. Existuje tzv „drůbeží mor" vyvolaný paramyxovirem. Choroba je známá jako „Newcastle disease“ a běžně se přenáší na člověka. Onemocnění je poměrnè lehké, chřipkové podoby. Tyto choroby přenášené ptáky a drůbeží pro

Adresa: prof. MUDr. Jaroslav Šimon, DrSc., Centrum preventivní kardiologie, II. interní klinika, Lékařská fakulta Univerzity Karlovy, E. Beneše 13, 30599 Plzeň, Česká republika, e-mail: Jaroslav.Simon@lfp.cuni.cz obecné povědomí neexistují, protože se o nich v mediích nic nepíše. Naše obavy o zdraví a panické hrůzy $\mathrm{z}$ chorob jsou nepochybně $\mathrm{v}$ rukou medií, at' už chceme nebo nechceme. Racionalita lidstva je nízká, říká se, že lidstvo jako celek nemá mozek. Mozek má jen člověk.

Pohybujeme se od narození v riziku chorob, které nám poškodí zdraví, zhoršují kvalitu života, nebo nás dřive nebo později zahubí. Riziko postižení populace chorobou nebo určitou poruchou označujeme zkratkou GBD (Global Burden of Disease). Vyjadřuje, kolik procent určité populace pravděpodobně zemře do určitého věku na určitou poruchu. ${ }^{(1)}$ Příčiny GBD se liší $\mathrm{v}$ různých populačních geografických a socioekonomických oblastech. Přičiny GBD jsou odlišné $\mathrm{v}$ plně ekonomicky rozvinutých populacich (první svět), v rozvijjejících se populacích (druhý svět) a ekonomicky nerozvinutých primitivnich populacích Afriky, Asie a Jižní Ameriky (třetí svět). Co je pro populaci nejvíce nebezpečné $\mathrm{v}$ těchto rozdílných oblastech ukazují sloupcové grafy (obrázek 1). Mưžeme se tedy dozvědět, co nás skutečně nejvíce ohrožuje, a to bezprostředně, a o čem by měla media stále psát.

Podvýživa, infekce HIV a také asi H5N1 v současné době ohrožuje zejména populaci třetího světa. Lidé zde umíraji časněji na podvýživu a infekce než je mưže zahubit kouření, hypertenze, diabetes a obezita, což jsou zdravotní poruchy charakteristické pro naši populaci. Co nám tedy bezprostředně dnes nejvíce škodí je kouření, hypertenze, obezita, diabetes mellitus a dyslipidemie. Kladu si otázku, zda by mediální kampaně dokázaly vyvolat u naší populace a jinde ve světě paniku $z$ onemocnění karcinomem plic a ICHS, která by priméla obyvatelstvo vybíjet trafiky a pálit tabák $z$ důvodu, že je to přesně to, co je bezprostředně ohrožuje. Takové akce by byly $z$ hlediska skutečného GBD více racionální místo vybíjení ptáků a drůbeže a možná koček a psů. Boji proti obezitě a dyslipidemii by pomohlo, kdyby nabídka pohoštění v restauracích vypadala tak, jak ji nakreslil Sydney Harris (obrázek 2).

Platí, že zdraví a prevence chorob není zadarmo, nicméně některé výdaje by měly být vratné. Výdaje na zabezpečení Tamilu pro statisíce obyvatel byly nepochybně nutné. Je málo pravděpodobné, že se budou 


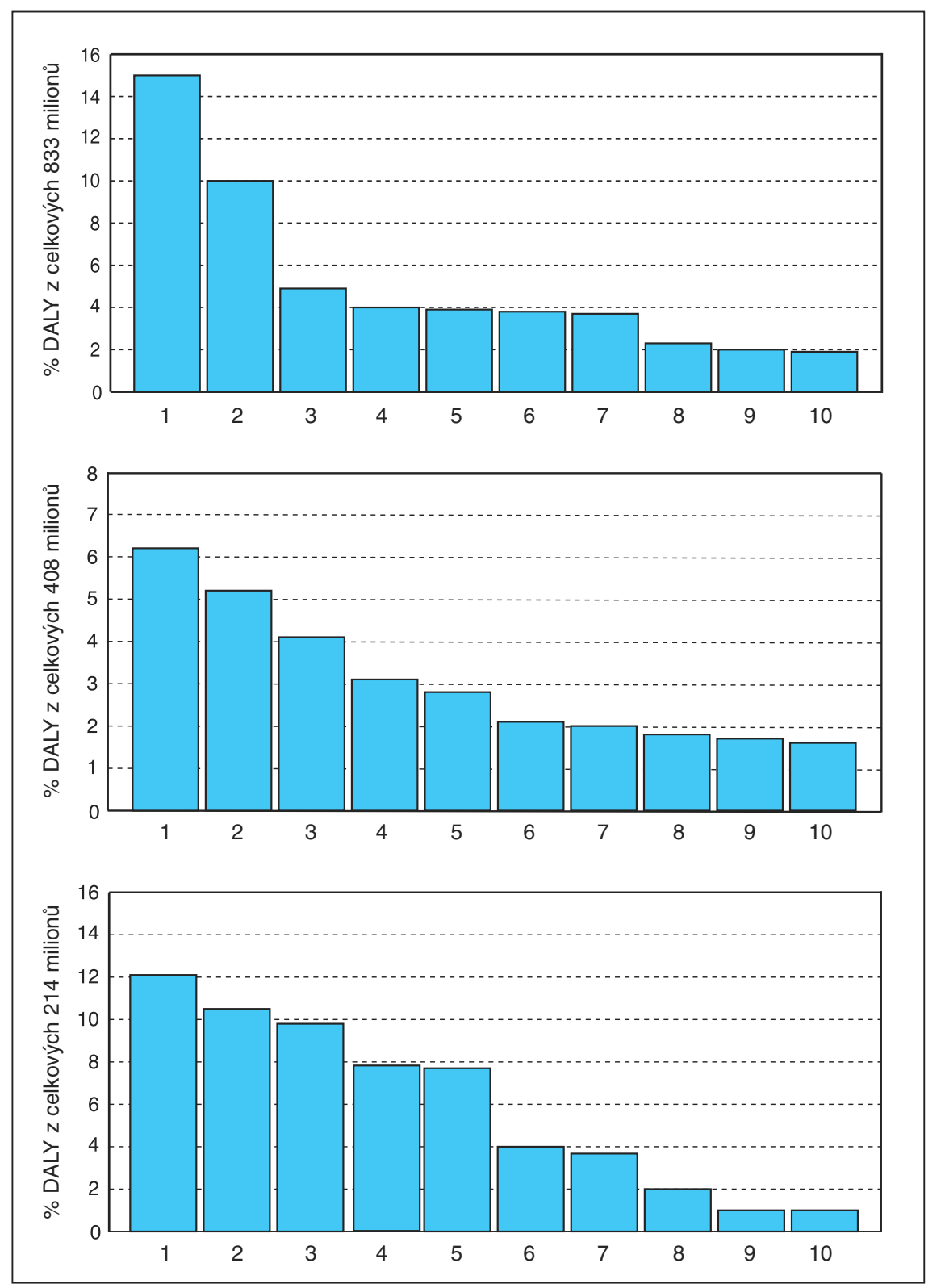

Obr. 1 a Třetí svět

1 - podvýživa

2 - rizikové sexuální chování

3 - znečištěná voda, špatná osobní a komunální hygiena

4 - kouř $\mathrm{z}$ tuhých paliv

5 - nedostatek zinku

6 - nedostatek železa

7 - nedostatek vitaminu A

8 - vysoký krevní tlak

9 - kouření tabáku

10 - vysoký cholesterol

Obr. 1 b Druhý svět

1 - alkohol

2 - vysoký krevní tlak

3 - kouření tabáku

4 - nízká hmotnost

5 - nadváha

6 - vysoký cholesterol

7 - nízký príjiem ovoce a zeleniny

$8-$ kouř $z$ fosilních paliv

9 - nedostatek železa

10 - špatná voda, osobní a komunální hygiena

Obr. 1 c První svět

1 - kouření tabáku

2 - vysoký krevní tlak

3 - alkohol

4 - vysoký cholesterol

5 - obezita

6 - nízký př́jem ovoce a zeleniny

7 - nízká fyzická aktivita

8 - drogová závislost

9 - rizikový sex

10 - nedostatek železa

Obr. 1 a, b, c Relativní vliv deseti různých faktorů na počet DALY (Disability Adjusted Life Years - počet let života populace bez manifestní choroby vedoucí k tělesné nebo duševní neschopnosti) v populacích s rozdílnou socio-ekonomickou strukturou Upraveno podle Ezzati M, et al.(1)

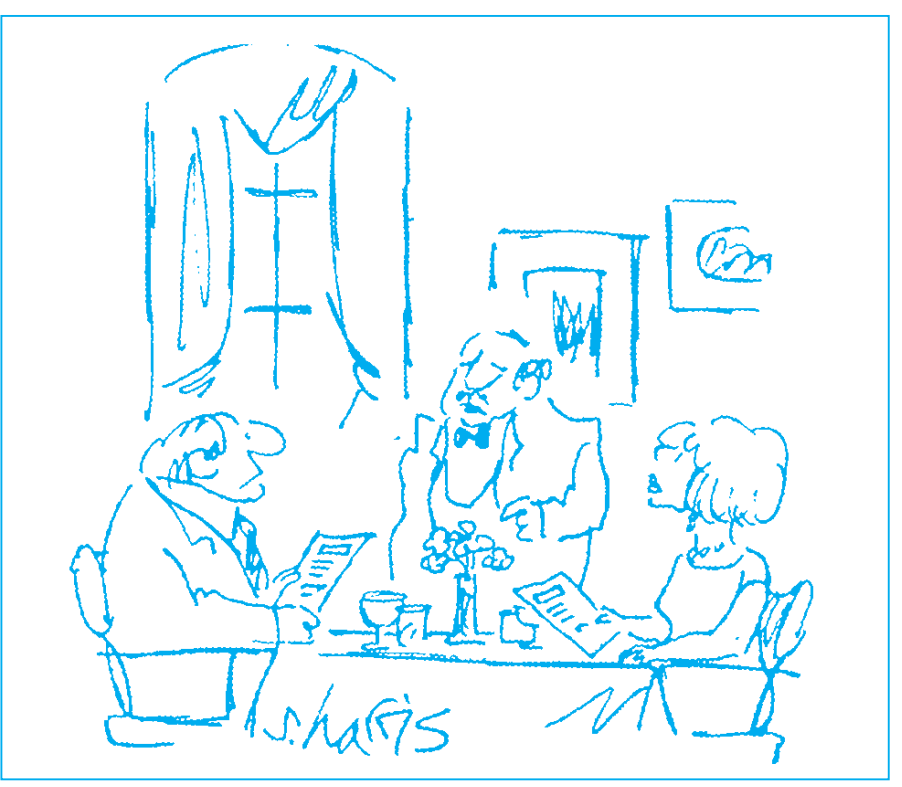

Obr. 2 Dovoluji si však upozornit, že podle hlavního hygienika mohou být všechna jídla $z$ naší restaurace vlastně zdraví nebezpečná rentovat; avšak ten, kdo rozhoduje a nese riziko musí být alibista a i trochu demagog. Lék s pravděpodobností hraničící s jistotou projde a bude zlikvidován.

Lidé se nejvíce strachují nebo se naopak těší na to, co má nejmenší pravděpodobnost, že se uskuteční. Vyhrát jackpot ve sportce, a dostat infekci H5N1 má podobnou pravděpodobnost kolem $100 / 10^{10}$.

Je geneticky zakódováno, že se bojíme více neznámého, tajemného, nepravděpodobného a neovlivnitelného, než toho, co nás s vysokou pravděpodobností čeká. Jezdíme po D1 do Brna, kouřime, pijeme, lenošíme a přejídáme se. Prevence chorob, které nás skutečně s velkou pravděpodobností očekávají, není ani populární ani mediálně zajímavá. Konečně strach ze smrti, která nás nemine má každý, ale každý z nás si myslí, že zrovna my u toho nemusíme být.

\section{LITERATURA}

1. Ezzati M, Lopez AP, Rodgers J, et al. Selected major risk factors and global and regional burden of disease. Lancet 2002;360:1347-60. 